\title{
Unusual case of odontogenic maxillary sinusitis
}

\author{
Marina Brimioulle, Ketan Desai
}

Ear, Nose and Throat department, Brighton and Sussex University Hospitals NHS Trust, Brighton, UK

\section{Correspondence to} Dr Marina Brimioulle, marina. brimioulle@gmail.com

Accepted 4 July 2017

\section{CrossMark}

To cite: Brimioulle $\mathrm{M}$, Desai K. BMJ Case Rep Published Online First: [please include Day Month Year]. doi:10.1136/bcr-2017220911

\section{DESCRIPTION}

A 76-year-old woman presented with intermittent infection around the upper right 2 (UR2) area of the maxilla for several years. She also complained of persistent rhinorrhoea and right-sided facial pain.

Seven years previously, she had presented with similar right maxillary pain, after undergoing root canal treatment of the UR2, 3 and 4 teeth. An orthopantomogram had shown uptake around the UR2 region (figure 1). There was a suspicion of retained tooth fragment, and she underwent a Caldwell-Luc procedure under local anaesthetic but no tooth fragment was identified at surgery.

Examination revealed a sinus draining buccally around UR2 and a fluctuant swelling of the palate. She was tender over the right maxilla. Nasal endoscopy did not demonstrate any purulent discharge from the right middle meatus.

A CT scan identified (1) opacification of the sinus, (2) a calcified $7 \mathrm{~mm}$ mass of tooth density in the inferior third of the sinus and (3) an oroantral fistula with an expanded area around UR2 consistent with an abscess cavity, confirming the diagnosis of odontogenic maxillary sinusitis (figure 2).

The patient was treated with antibiotics and she underwent functional endoscopic sinus surgery, during which a dental root was formally identified and removed from the right maxillary sinus (figure 3). Following this, the patient made a complete recovery.

Odontogenic causes account for up to $30 \%-40 \%$ of maxillary sinusitis, the most common being of iatrogenic origin. As demonstrated in this case, without

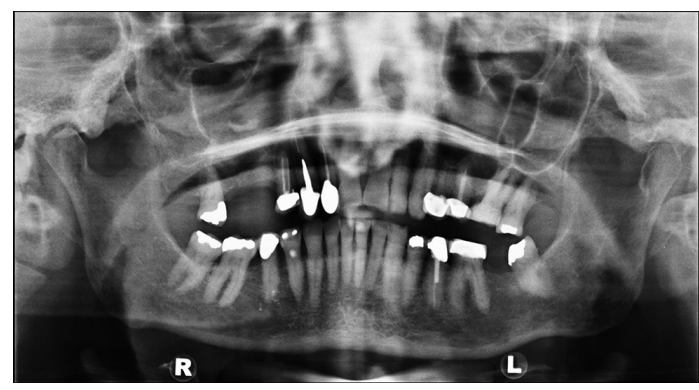

Figure 1 Orthopantomogram.
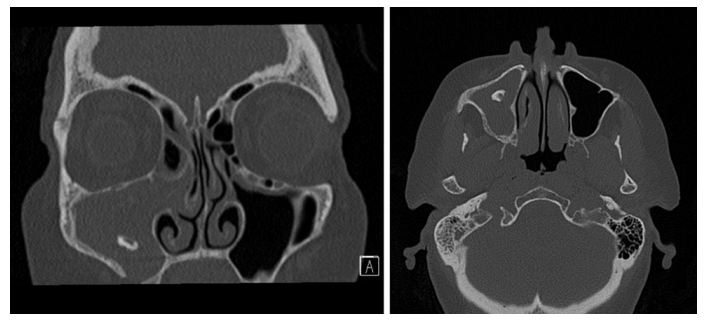

Figure 2 CT scan of sinuses, coronal and axial views of the maxillary sinus.

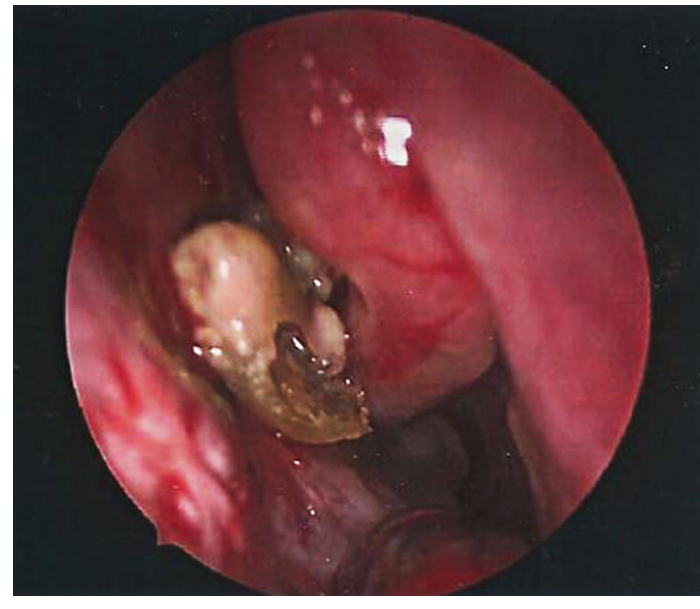

Figure 3 Tooth fragment at the right middle meatus during functional endoscopic sinus surgery.

\section{Learning points}

- An odontogenic cause should be suspected in non-resolving cases of unilateral maxillary sinusitis, particularly in the presence of dental symptoms but equally in their absence.

- $\mathrm{CT}$ is the gold standard investigation to diagnose odontogenic maxillary sinusitis. Cone beam CT can also be used to evaluate maxillary sinus disease when suspecting an odontogenic cause. ${ }^{2}$

- Management of odontogenic maxillary sinusitis includes treatment of both the dental cause and the sinusitis, which often includes functional endoscopic sinus surgery or an open procedure as well as antibiotic therapy.

identifying and addressing the cause of sinusitis, the infection will remain untreated despite attempts at medical and surgical management.

Contributors MB prepared the manuscript. KD reviewed the manuscript and provided the intraoperative images.

Competing interests None declared.

Patient consent Obtained.

Provenance and peer review Not commissioned; externally peer reviewed.

Published by the BMJ Publishing Group Limited. For permission to use (where not already granted under a licence) please go to http:// www.bmj.com/company/products-services/rights-and-licensing/

\section{REFERENCES}

1 Simuntis R, Kubilius R, Vaitkus S. Odontogenic maxillary sinusitis: a review. Stomatologija 2014;16:39-43.

2 Shahbazian M, Jacobs R. Diagnostic value of 2D and 3D imaging in odontogenic maxillary sinusitis: a review of literature. J Oral Rehabil 2012;39:294-300. 
Images in...

Copyright 2017 BMJ Publishing Group. All rights reserved. For permission to reuse any of this content visit http://group.bmj.com/group/rights-licensing/permissions.

BMJ Case Report Fellows may re-use this article for personal use and teaching without any further permission.

Become a Fellow of BMJ Case Reports today and you can:

- Submit as many cases as you like

- Enjoy fast sympathetic peer review and rapid publication of accepted articles

Access all the published articles

- Re-use any of the published material for personal use and teaching without further permission

For information on Institutional Fellowships contact consortiasales@bmjgroup.com

Visit casereports.bmj.com for more articles like this and to become a Fellow 